\title{
Childhood Fibrosarcoma
}

National Cancer Institute

\section{Source}

National Cancer Institute. Childhood Fibrosarcoma. NCI Thesaurus. Code C8088.

A malignant neoplasm arising from the deep soft tissues in children. It is characterized by the presence of spindle-shaped fibroblasts and collag enous stroma formation in a herring bone growth pattern. 